\title{
BENDA PURBAKALA DARI PURA TULUKBIYU DI BALI
}

\section{Sukarto Karto Atmodjo}

Keywords: heritage; Bali; epigraphy; temples; hindu

\section{How to Cite:}

Atmodjo, S. K. (1987). BENDA PURBAKALA DARI PURA TULUKBIYU DI BALI. Berkala Arkeologi, 8(1), 31-45. https://doi.org/10.30883/jba.v8i1.484

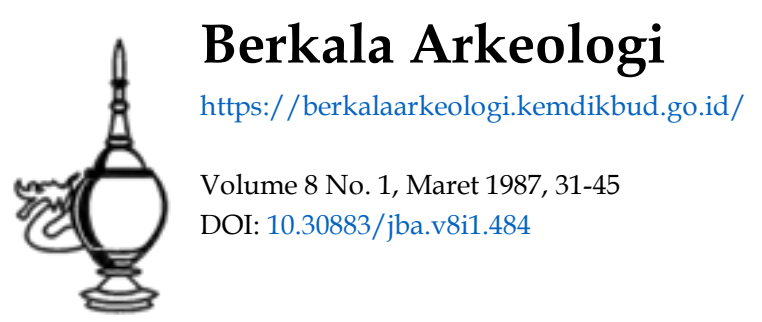




\title{
BENDA PURBAKALA DARI PURA TULUKBIYU DI BALI
}

\author{
Oleh: M.M. Sukarto K Atmodjo
}

Bali bezit een oude beschaving, waarin heterogene elementen uit verschillende perioden zijn samengesmolten tot een geheel, dat zich steeds wist aan te passen bij de eisen van een niuwe tijd.'

Th.P. Galestin: Hedendaagse Kunst van Bali, Centraal Museum, Utrecht, 1962 (Inleiding, hlm. 9).

Di desa Batur (Kecamatan Kintamani, Kabupaten Bangli, Propinsi Bali) terdapat sebuah pura (bangunan suci umat Hindu), yang sampai sekarang masih menyimpan beberapa buah benda purbakala yang sangat penting. Pura itu seakan-akan terlepas dari perhatian para sarjana Arkeologi karena bentuknya memang tidak jauh berbeda dengan pura lainnya di pulau Bali. Oleh penduduk setempat pura itu disebut Pura Tulukbiyu (biyu: pisang) ${ }^{2}$ dan terletak di sebelah timur jalan raya yang menghubungkan Bangli dengan Singaraja. Desa Batur sendiri terletak berbatasan dengan desa Kintamani yang sangat terkenal di sebagian dunia karena hawanya yang sejuk dan pemandangan alamnya yang indah. Demikian pula Pura Tulukbiyu berbatasan temboknya (pênyêngkêr) dengan Pura Ulun Danu Batur yang cukup terkenal. Bahkan sepintas pandang Pura Ulun Danu dan Pura Tulukbiyu, keduanya seakan-akan merupakan sebuah kompleks pura yang besar. Di dalam Pura Ulun Danu Batur masih tersimpan beberapa cakèp lontar Rajapurana yang telah diteliti dan diterbitkan (stensilan) oleh Museum Bali. ${ }^{3}$ Sebuah di antaranya, yaitu Babad Patisora. sangat penting ditinjau dari segi Epigrafi (Ilmu Prasasti), khususnya yang berkaitan dengan masalah kronogram (sêngkalan). ${ }^{4}$ Selain 
yang berkaitan dengan masalah kronogram (sêngkalan). ${ }^{4}$ Selain nama Pura Tulukbiyu penduduk setempat juga menyebut dengan nama lain, yaitu Pura Batur Kanginan (kangin: timur). Dipandang dari segi arsitektur bangunan Pura Ulun Danu memang kelihatan lebih megah dengan atap meru dan pintu gerbangnya yang menjulang tinggi dan tampak jelas apabila pengunjung datang dari arah Selatan (dari Pênelokan). ${ }^{5}$ Ternyata di dalam Pura Tulukbiyu sampai sekarang masih tersimpan benda-benda purbakala yang sangat penting dan jauh lebih menarik dibanding dengan benda-benda purba lainnya di dalam pura sekitarnya. Bahkan juga tidak kalah pentingnya dipandang dari segi arkeologi apabila dibanding dengan Pura Têgêh Koripan di gunung Pênulisan yang terletak sekitar $6 \mathrm{~km}$ di sebelah Utara Kintamani. Benda-benda purbakala yang tersimpan di Pura Tulukbiyu itu berupa beberapa buah prasasti kuna, arca keramik (porselin), arca mas yang sangat berharga, dan benda-benda peralatan (perlengkapan) pura lainnya.

Sebelum melangkah lebih jauh perlu dijelaskan bahwa nama Kintamani yang lebih terkenal dibanding dengan Batur, sebetulnya merupakan perubahan atau kekeliruan ucapan dari Cintamani. Dalam prasasti Cintamani yang bertarih 804 Saka (882 M) disebut nama bukit Cintamani (bukit: bukit). Prasasti itu dicatat oleh R. Goris dengan nama prasasti Sukawana A I (Goris No. 001). ${ }^{6}$ Perubahan nama Cintamani menjadi Kintamani dapat dibanding misalnya nama kerajaan Colamandala di India Selatan yang kemudian berubah ucapannya menjadi Koromandel. Seperti telah diketahui kesenian Cola berkembang antara abad IX dan abad XIV Masehi. Perkataan Cintamani berarti 'manikam percintaan' (Belanda: juweel der liefde). Dalam buku Iconographic Dictionary of the Indian Religions karangan Gösta Liebert (Leiden, E.J. Brill, 1976) mengenai Cintãmañi antara lain dikatakan sebagai berikut: cintãmaṇi (orig. "thought-gem, a jewel which grants all wishes" (attr. esp. Buddh.), name of a pearl surrounded with flames. The cintãmani represents in Buddhism the manas or the 6th sense, and it also stands for triratna. This attr. is often not distinguishable from the simpler form ratna ("pearl"), and in 
this dictionary (as far as Buddhist icons are concerned) cintãmaṇi is used as a common name for cintãmani and ratna. Some Buddhaforms have, instead of an ușnișa, a high hair-crown, which has a cintãmani on its top. In South India this attribute is explained as a flame, compare agni. In Hinduism cintãmani is a "gem supposed to yield its possessor all desires" (M. Monier Williams: A SanskritEnglish Dictionary). This attribute may be held in a hand or worn on the body (hlm. 62). Selain itu pada halaman yang sama juga disebut cintãmanidhuaja ("banner marked with a jewel, jewel = banner") dan Cintãmani:Lokeśvara (Lokeśvara of the thought-gem", Buddha).

Berdasarkan uraian singkat di atas, maka dapat diperkirakan bahwa perkataan cintãmani yang semula berarti "thought-gem, a jewel which grants all wishes" kemudian dapat pula berarti "a jewel of love" (cf. bahasa Indonesia: cinta $=$ percintaan, asmara, mani $=$ manikam, air mani). ${ }^{7}$ Tidak jauh dari Kintamani terdapat pula nama sebuah desa yang menggunakan unsur nama mani atau manik (manikam, permata), yaitu desa Manikliyu (liyu: banyak). Dalam sebuah prasasti tembaga raja Jayaśakti yang bertarih 1055 Saka (1133 M) disebut nama Manikãlyu. Nama itu kemudian berubah menjadi Manikliyu sekarang. Berlainan dengan prasasti Cintamani yang menggunakan bahasa Bali Kuna maka prasasti Manikãlyu menggunakan bahasa Jawa Kuna. Oleh R. Goris prasasti itu dicatat menjadi prasasti Manikliu D = Lambean A (Goris No. 551). Berdekatan dengan Manikliu terletak desa Langgahan yang masih menyimpan sebuah prasasti dari raja Astãsura-ratna-bumi-bantên yang bertarih 1259 Saka (1337 M). ${ }^{8}$ Prasasti itu menyebut nama desa Patapan Langgaran yang kemudian berubah menjadi Langgahan (Goris No. 811).9

Menurut keterangan penduduk. Pura Tulukbiyu atau Pura Batur Kanginan dahulu merupakan hasil pemindahan dari desa Abang yang terletak di bawah, artinya di pinggir danau Batur. Demi keamanan benda-benda keramat yang disimpan dan juga untuk menghindari akibat langsung letusan Gunung Batur, maka pura tersebut kemudian dipindah ke atas, artinya ke tempat yang lebih aman. Keterangan ini 
sesuai dengan kenyataan, karena prasasti yang tersimpan di Pura Tulukbiyu juga menyebut nama desa Air Hawang (1011 M) yang kemudian berubah menjadi $\mathrm{Er}$ Abang (1181 M), dan akhimya menjadi desa Abang (cf. Gunung Abang). Nama itu pun kalau diteliti lebih jauh berasal dari nama desa Air Rawang (banua di air rawang) yang disebut dalam prasasti Turuñan (Trunyan B, Goris No. 004) dan berangka-tahun 833 Saka (911 M). ${ }^{10}$

Perlu diketahui bahwa jumlah pênyiwi (pênyungsung) Pura Tulukbiyu sekarang kira-kira sebanyak 250 kepala keluarga. Pemandangan di sekitar pura sangat indah, karena di sebelah Timur terlihat puncak Gunung Batur yang sewaktu-waktu mengeluarkan asap dan juga terlihat danau Batur yang sangat terkenal dan menyerap kunjungan wisatawan yang berjubel memandangnya dari desa Pênelokan (sebelah tenggara Batur-Kintamani). Dari Pênelokan inilah terdapat jalan aspal menurun menuju pinggir danau Batur (desa Kêdisan) dan selanjutnya dapat mengunjungi Buwahan, Trunyan, dan Songan. Pada jaman dahulu desa-desa yang terletak di pinggir danau Batur disebut dengan istilah wingkang ranu yang berarti: pinggir danau (wingkang: pinggir, ranu: danau Batur). Karena salah pengertian maka perkataan wingkang ranu lambat laun berubah menjadi wintang ranu (bintang danu) dan dikaitkan oleh sementara orang dengan pengertian bintang (Goris: Prasasti Bali II, hlm. 336). ${ }^{11}$

Sayang sekali mengenai asal dan arti nama Pura Tulukbiyu penduduk tidak dapat memberi jawaban yang jelas. Mereka hanya mengatakan bahwa perkataan biyu berarti pisang, tetapi tuluk tidak jelas artinya. ${ }^{12}$ Untunglah dalam prasasti Air Hawang (1011 M) disebut nama Bhațāra Kulitbiyu dan dalam prasasti Er Abang (1181 M) disebut nama Bhatāa ri Tulukbiyu. Jelaslah bahwa dalam jangka waktu kira-kira 170 tahun terjadi perubahan nama dari Kulitbiyu menjadi Tulukbiyu. Dengan demikian dapat diperkirakan bahwa perkataan kulitsetidak-tidaknya mempunyai kemiripan pengertian dengan tuluk. Mungkin juga merupakan sinonimnya dalam arti yang luas. Dalam bahasa Jawa Kuna perkataan kulit selain berarti kulit, 
juga berkaitan dengan istilah kulit kaki yang diterjemahkan oleh Prof. Dr. P.J. Zoetmulder S.J. dengan paternal lineage? (dengan tanda tanya). ${ }^{13}$ Dalam Kamus Umum Bahasa Indonesia dari WJS Poerwadarminta (Balai Pustaka, 1976, hlm. 1084) perkataan tolok antara lain juga berarti: pohon, Incarpus edulis FORST. Seperti telah diketahui dalam bahasa Bali Kuna banyak terdapat unsur-unsur bahasa Melayu Kuna yang disebut Indonesisch oleh R. Goris (Prasasti Bali II, bagian Woordregister, hlm. 203-339).

Pengamatan lebih lanjut membuktikan bahwa yang dimaksud dengan Bhatāara Kulitbiyu adalah tokoh dewa-gunung (Lord of the mountain) yang berkuasa di atas bukit Kulitbiyu (sekarang Gunung Abang). Dalam prasasti Air Hawang disebut Sang Hyang Wukir Kulitbiyu (Dewa Bukit Kulitbiyu) dan juga nama Pungśu Kulitbiyu (Bukit Kulitbiyu). Dalam bahasa Bali atau Jawa Kuna perkataan wukir berarti bukit (gunung), demikian pula perkataan pungśu (bukit, cf. Jawa Baru puntuk). Lempengan Vlb prasasti Air Hawang yang menyebut: ... yan hana sang madewaśraya $i$ sanghyang wukir kulit byu... (. . . apabila terdapat seseorang yang memohon bantuan dewa kepada yang mulia gunung Kulitbiyu ...) membuktikan bahwa Bhațāra Kulitbiyu memang seorang tokoh dewa-gunung yang sangat dikeramatkan. Selanjutnya dapat ditentukan pula bahwa dewagunung (Parvateśwara) tersebut yang dimaksud ialah dewa Siwa. Hal ini dibuktikan, bahwa sampai sekarang di dalam Pura Tulukbiyu (Batur Kanginan) masih tersimpan dua buah arca mas yang disebut Bêtara Tulukbiyu dan Bêtari Tulukbiyu. Sewaktu penulis diperbolehkan langsung melihatnya, ${ }^{14}$ jelas bahwa dua buah arca (prêtima) tersebut menggambarkan dewa Siwa dan dewi Pārwati (dewi Umā). Mengingat tradisi Bali yang sangat kuat, mungkin sekali arca mas Bêtara Tulukbiyu yang masih dikeramatkan atau disungsung tersebut memang menggambarkan Bhatāra Kulitbiyu (prasasti Air Hawang, 1011 M) atau Bhațāra Tulukbiyu (prasasti Er Abang, $1181 \mathrm{M}$ ). Apabila perkiraan ini benar, maka arca tersebut setidak-tidaknya telah berusia sekitar 850 tahun. Ditinjau dari segi ikonografi, sayang tidak boleh dipotret, perkiraan itu memang tidak jauh bertentangan. 
Seperti telah diterangkan di atas, di dalam Pura Tulukbiyu sampai sekarang masih tersimpan beberapa benda purbakala yang sangat penting berupa lebih-kurang 21 lembar prasasti tembaga (tāmra-prasasti), arca porselin, arca mas (Bêtara dan Bêtari Tulukbiyu), sangku, jambangan, batu setengah permata (half edelstenen), dan lain-lainnya. Benda-benda kuna yang dikeramatkan itu perinciannya sebagai berikut:

\section{A. Berupa Prasasti}

Prasasti ini merupakan prasasti tembaga yang disimpan dalam bangunan meru tumpang tiga bersama-sama benda kuna lainnya. Transkripsi dan terjemahan selengkapnya telah dikerjakan oleh R. Goris (P.B. I dan P.B. II). Pembacaan ulang dilakukan oleh penulis pada tanggal 16 Nopember 1974 di Pura Tulukbiyu. Prasasti yang tersimpan di Pura Tulukbiyu tersebut dapat dibedakan menjadi tiga bagian (kelompok), yaitu:

1. Prasasti Air Hawang

Oleh R. Goris disebut Batur, Pura Abang A (Goris No. 305). Isi pokok antara lain sebagai berikut:

a. Bertarih 933 Saka (1011 M),

b. Menyebut nama raja Päduka Śri Dharmmodayana Warmadewa,

c. Menggunakan bahasa dan huruf Jawa Kuna (Kawi) dengan beberapa perkataan Bali Kuna,

d. Menyebut daerah karaman-i wingkang ranu air hawang (desa pinggir danau di Air Hawang), ${ }^{15}$

e. Menguraikan masalah pemeliharaan kuda (tangkalik kuda) dan menyebut pejabat tinggi urusan kuda dengan pangkat rakryanasba bernama Dyah Mañjak (rakryan: rêkayana dalam bahasa Jawa Baru, asba: kuda, aswa). Kuda sangat penting waktu itu untuk mengangkut barang dagangan antara Bali bagian pedalaman dengan daerah pantai. Juga penting untuk angkutan manusia (binatang transport),

f. Menyebut nama Bhațāra Kulitbiyu. 


\section{Prasasti Er Abang}

Oleh R. Goris disebut Batur, Pura Abang B (Goris No. 605). Isi pokok antara lain sebagai berikut:

a. Bertarih 1103 Saka (1181 M),

b. Menyebut nama raja Pāduka Srī Mahārāja Haji Jayapangus Arkajacihṇa Arddhanaríśwarisanasini. Raja mengaku sebagai putra (keturunan) matahari (arkaja). Selain itu juga menyebut permaisuri raja yaitu Pāduka Srì Mahādewī Śri Sasangkajaketana yang mengaku sebagai putri keturunan bulan (sasangkaja), ${ }^{16}$

c. Menggunakan bahasa dan huruf Jawa Kuna,

d. Menyebut nama desa Er Abang,

e. Menyebut nama Bhaţāra ri Tulukbiyu (ri: di),

f. Berisi penyelesaian pertikaian yang timbul antara penduduk desa Er Abang dengan para pejabat pemerintahan sang-admakakmitan-apigajih. ${ }^{17}$

\section{Prasasti Her Abang}

Oleh R. Goris disebut Batur, Pura Abang C (Goris No. 901). Ditinjau dari segi paleografi (Ilmu Tulisan Kuna), prasasti ini merupakan prasasti yang terindah hurufnya yang pernah diketemukan di Bali. Menggunakan huruf tipe Majapahit dan menyebut raja Wijayarājasa, yaitu raja Wêngkêr di Jawa Timur dan paman raja Hayamwuruk. Berita Cina menyebutnya Wu-yüan-lao-wang-chieh (kitab Ming-shih). Isi pokok antara lain sebagai berikut:

a. Bertarih 1306 Saka (1384 M),

b. Huruf dan bahasa Jawa Kuna Majapahit,

c. Menyebut nama raja dengan gelar sebutan yang cukup panjang, yaitu: Pāduka Sri Mahārāja Rājasaparameswara Srỉ Sakalaprajānandanakaraña Saradamala Saśangkasangkaśa Suddhasyaśowrajadaranijhāraṇa/ Maniśwaranaribhuta, Pāduka Parameśwara S̛̉ī Wijayarājasa Nāmadewabhişeka, ${ }^{18}$

d. Menyebut hubunganantara parasamya(penduduk) Her Abang dengan penduduk desa Pamutêran, antara lain: Pada waktu upacara 
(hari raya) di Her Abang yang jatuh pada pūrnamaning besaka (purnamaning kèdasa) penduduk Pamutêran supaya menyerahkan (asrah) pangacara (semacam upeti) kepada desa Her Abang berupa: padi (pari), kampuh (kampuh), ketan merah dan hitam (ktan-bang-irêng), tales (talês), pisang (gdang), ${ }^{19}$ tebu (tbu), jeruk manis (jruk manis) dan sajêng (minuman keras, tuak). Demikian pula pada waktu pürnamanaing katiga penduduk Pamutêran (ikang wwang pamutêran) supaya turun (letak Pamutêran di dataran lebih tinggi) ke Her Abang dengan membawa bunyi-bunyian saluṇding (nhêr-amawa salunding), dan pada waktu pürnamaning dyestha penduduk Pamuteran supaya menyerahkan pangarundung 3 tangkêp (prapta wwang pamutêran-asrah pangarundung, tangkêp 3) kepada penduduk Her Abang. Selain itu juga harus menyerahkan tebu dengan daunnya (tbu tkan-i ronya), sajêng (tuak) 2 pikul, pirak 1 masa, dodot balibah dan kampuh (kāmpuh). Selanjutnya pada tanggal satu bulan Waiśaka (ttanggal pisaning waiśaka) supaya menyerahkan (persembahan, oleh-oleh) balukbukan (?), jawa 1 ku (jewawut?), mentimun (antimun) 2, tales (keladi) yang dimasak (tậês kinulub), emping I ku hêmping, ku l) dan masaya (Jawa: mêsoyi?) kepada pejabat kabayan-atuha, kabayan nõman, ${ }^{20}$ argga tuha, argga ñoman, ${ }^{21}$ bahu tuha, bahu ñoman. ${ }^{22}$ panghet tuha dan panghet ñoman. ${ }^{23}$

e. Apabila penduduk Her Abang berkunjung ke Pamutêran dan kemudian pulang ke desanya (mantuk mare swadeśanya), mereka akan diantar oleh penduduk Pamutêran sampai ke Her Abang selama sepekan ( 3 atau 5 hari). Mereka membawa bekal berupa: nasi (sku), masakan (mararatngan), ikan babi berat 3000 (ulamnya babi, bwat, 3000), hisi berat 3000 , balung (tulang) berat 3000 , bulan (?) berat 400 , kocok (?) berat 400 , ketan hitam 1 pikul, tales masak 2 pikul, dodot balibah, tuak 5 guci (sajêngnya, guci, 5), dan masakan (raratngan) satu kahu (sakahu). Selanjutnya juga dijelaskan bahwa tanggal penyerahan itu ditetapkan pada tanggal satu bulan Wesaka, jika tidak, penduduk Pamutêran diharuskan menggiring (menyerahkan) 800 ekor celeng (tuhun-mäsanikang 
wwang pamutêran-srah, tanggal-pisaning weśaka, tuhun-yan-tanpasrah-i-kala samangkana, iniridan-tekang wwang pamutêranceleng, ji, 800),

f. Disebut batas-batas desa Her Abang, dan juga letak Her Abang di sebelah utara gunung (ikang loring gunung her-abang) selanjutnya letak Pamutêran di sebelah Selatan gunung (ikang kiduling gunung, pamutêran). Mungkin yang dimaksud gunung di sini gunung Kulitbiyu (G. Abang sekarang). Sedangkan letak desa Putêran (Pamutêran) sekarang di daerah Kecamatan Rèndang, Kabupaten Karangasêm. Prasasti Putêran (Pamutêran) dicatat $\mathrm{R}$. Goris dengan nomer 502 (Pangotan B I).

\section{B. Berupa Arca}

Sampai sekarang di Pura Tulukbiyu setidak-tidaknya tersimpan tiga buah arca yang sangat penting, baik dipandang dari segi keagamaan maupun dari segi arkeologi. Keterangannya sebagai berikut:

\section{Arca dari Tiongkok}

Sebuah arca porselin (keramik) dari Tiongkok berupa seekor binatang gaib (mythical animal) menyerupai singa (harimau), setinggi lebih-kurang $35 \mathrm{~cm}$ (tidak dapat diukur dan difoto karena dikeramatkan). Menggunakan glasur berwarna-warni yang sangat indah. Mungkin berasal dari jaman kerajaan Ming atau sekitar abad XIV Masehi.

\section{Arca Bettara dan Bețari Tulukbiyu}

Dua buah arca (prêtima) menggambarkan dewa Siwa (dewa gunung) dan Pārwati (Umā), setinggi lebih kurang $30 \mathrm{~cm}$. Bahan dari mas dan sangat indah dipandang dari segi ikonografi. Para pênyiwi pura menyebut Bêtara Tulukbiyu dan Bêtari Tulukbiyu. Mung. kin sekali menggambarkan Bhațāa Kulitbiyu (pras. Air Hawang, $1011 \mathrm{M}$ ) atau Bhațāra Tulukbiyu (pras. Er Abang, $1181 \mathrm{M}$ ). Ditinjau dari segi arkeologi, kedua buah arca mas tersebut tidak kalah pentingnya dibanding dengan temuan arca mas yang menggambarkan Siwa dan Pārwatî̀ dari Gêmuruh (Wonosobo), yang dimuat dalam buku 
Ancient Indonesian Art dari Prof. Dr. A.J. Bernet Kempers (Gambar No. 33), dan juga temuan arca mas dan perak yang menggambarkan dewa Siwa dan Pārwati dari gua Sêplawan (Purworêjo). Karena arca Bêțara dan Bettari Tulukbiyu tersebut dianggap sangat keramat, maka hanya para pendeta, pêmangku, beberapa orang tua dan penulis diperbolehkan masuk ke dalam tempat penyimpanan dan diperkenankan melihatnya. Namun demikian, yang diperbolehkan memegang hanya pendeta (pemangku) saja, sehingga ukuran arca mas tersebut hanya merupakan perkiraan belaka. Demikian pula mengambil gambar foto tidak diperkenankan. Meskipun terdapat beberapa larangan (pantangan), penulis merasa puas dan bergembira karena diperbolehkan langsung menatap wajah prêtima Bêtara Tulukbiyu dan Bêțari Tulukbiyu, sedangkan para pênyiwi Pura Tulukbiyu sendiri (dan orang Bali lainnya) sulit dapat melihatnya (kecuali pendeta, pêmangku dan orang-orang tua tertentu). Akhirnya setelah mengamati dan membaca prasasti yang tersimpan di Pura Tulukbiyu, kedua arca tersebut kemungkinan besar menggambarkan Bhațara Kulitbiyu atau Bhațära Tulukbiyu yang disebut-sebut dalam prasasti Air Hawang (1011 M) atau Er Abang (1181 M). Mengapa prasasti tidak menyebut tokoh bhatari, mungkin karena tokoh bhațāra (dewa Siwa) atau tokoh laki-laki dianggap lebih penting dan lebih utama dibanding dengan tokoh wanita. ${ }^{24}$ Demikian pula lambang phallus (lingga) dalam arkeologi klasik lebih banyak ditonjolkan dibanding dengan lambang vulva (yoni). Hal ini dapat dilihat misalnya gambar pahatan phallus yang tegak (ūrddhvareta) di atas huruf dari prasasti batu Samirana. ${ }^{25}$

\section{Berupa Benda Kuna Lainnya}

Benda-benda kuna lainnya yang tersimpan di Pura Tulukbiyu bermacam-macam, sebagian merupakan alat kelengkapan keagamaan, dan sebagian lainnya rupa-rupanya alat kelengkapan dapur (paon). Perlengkapan dapur itu tentu saja hanya digunakan pada waktu diadakan upacara piodalan. Selain beberapa butir batu setengah permata (semacam batu akik), benda-benda kuna itu berupa sangku, jambangan dan alat-alat lainnya dari tembaga (perunggu). Memang 
harus diakui bahwa benda-benda itu tidak terlalu tua dibanding dengan benda-benda lainnya yang berupa prasasti dan prêtima. Namun demikian juga tidak boleh diabaikan sama sekali.

Sebagai penutup karangan singkat ini penulis menghimbau kepada semua fihak, baik para pènyiwi Pura Tulukbiyu atau aparat pemerintahan setempat, agar lebih berhati-hati mengawasi dan menjaga keselamatan benda-benda kuna yang tersimpan di dalam Pura Tulukbiyu. Lebih-lebih apabila diingat bahwa benda-benda purba tersebut juga mempunyai nilai keagamaan yang luar biasa dan masih tetap disungsung (dihormati). Himbauan ini mengingat meluasnya dan lubernya arus wisatawan di Balipulina (Balidwipamandala) yang selalu meningkat dan berkembang pesat. Lubernya wisatawan tersebut pasti membawa dampak positif maupun negatif. Dampak negatif akan mempercepat proses pengeringan budaya (cultural drain) dan meningkatnya pencurian benda-benda purbakala (benda budaya) yang tersimpan di dalam pura. Lebih menyedihkan lagi apabila pencurian benda budaya (purba) tersebut tidak hanya dilakukan oleh pencoleng dari luar Bali, tetapi juga oleh warga desa sendiri. Dapat diduga bahwa hilangnya benda-benda budaya dari pulau Bali tersebut antara lain juga didalangi oleh orang asing tertentu yang bermukim relatif cukup lama di Bali. 26

Sekian dan terima kasih.

IN OMNIBUS CARITAS (DALAM SEGALANYA CINTAKASIH). 


\section{CATATAN}

1. Tulisan Prof. Dr. Th. P. Galestin itu berarti sebagai berikut: Bali memiliki kebudayaan (peradaban) lama, yang merupakan percampuran bermacam-macam unsur dari berbagai macam jaman, dan yang selalu mampu menyesuaikan diri dengan tuntutan jaman baru.

2. Perkataan tuluk berarti: sogok (memasukkan), misalnya nulukin sahang (memasukkan kayu bakar). Ada pula yang mengatakan bahwa perkataan tuluk juga berkaitan dengan ngangget (Jawa: nyengget), artinya: menjolok. Tetapi berdasarkan data prasasti jelas bahwa nama Tulukbiyu $(1181 \mathrm{M})$ berasal dari nama Kulitbiyu (1011 M).

3. Berjudul: Rajapurana Pura Ulun Danu Batur Kitamani-Bangli, oleh Drs. Putu Budiastra dkk, tahun 1979.

4. Dalam Babad Patisora misalnya dikatakan: lawasing sgara rupekk, jaladi hannanggung bumi, 124, artinya: lamanya segara rupekk (laut sempit, selat Bali) pada tahun jaladi (4) hannanggung (2) bumi (1), jadi tahun 124 Saka. Perkataan lawasing berarti: lamanya, pada waktu terjadinya peristiwa. Mengenai gunung Tulukbiyu dikatakan: lawasing gunung tulukbiyu, nga, 112. Tetapi di sini tidak jelas peristiwa apakah yang berkaitan dengan gunung Tulukbiyu pada tahun 122 Saka tersebut. Selain itu juga dikatakan: lawasing segara lor jung nnibekk ring natar, 149, yang berarti: lamanya lautan utara membanjiri halaman, tahun 149 Saka. Rupa-rupanya kalimat jung nnibêk ring natar melambangkan tahun 149 , meskipun kurang jelas (jung: 9 , nnibêk: 4, natar: 1).

5. Dinamakan Pênelokan karena memang jalannya berkelok kelok. Dari Pênelokan para wisatawan dapat menikmati keindahan G. Batur dan danau Batur. Sayup. sayup sampai juga kelihatan desa Trunyan yang sangat menarik. Demikian pula puncak $\mathrm{G}$. Abang apabila cuaca cerah kelihatan jelas.

6. Lihat Prasasti Bali I (P.B. I), hlm. 53, baris 1 dan 2 lempengan Ib. Di desa Cintamanik (daerah Bumijawa, Jawa Tengah) pernah diketemukan arca-arca Polinesia dan batu bulat dengan lobang di tengahnya (dari tingkatan megalitikum?).

7. Lihat misalnya M.M. Sukarto: "The Phallic Symbol On The Stone Inscription Of Samirana", dalam buku Untuk Bapak Guru, Persembahan para murid untuk memperingati usia genap 80 tahun Prof. Dr. A.J. Bernet Kempers, hlm. $173-$ 188 (Pusat Penelitian Purbakala, Jakarta, Dep. Pendidikan, 1986).

8. Lihat M.M. Sukarto: "Betulkah Asțāsura-ratna-bumi-bantên seorang raja Bali yang murka dan hina (?)", makalah pada Seminar Sejarah Nasional III, Jakarta, tahun 1981. Selanjutnya lihat juga M.M. Sukarto: "Mengapa Phallus Arca SiwaBhairawa Di Pura Kêbo Edan Menghadap Ke Arah Kiri?", Berkala Arkeologi, Maret 1983, hlm. 48-54.

9. Perubahan Langgaran menjadi Langgahan dapat dibandingkan dengan Sakar menjadi Sakah, Darusa menjadi Dausa, Gurang menjadi Guang, dll. Pendek kata suara r kemudian dihilangkan. Perlu ditambahkan di sini bahwa prasasti Patapan Langgarandisimpan terpendam di bawah sebatang pohon di dalam hutan. 
Tempat itu sangat dirahasiakan dan hanya beberapa orang penduduk desa yang mengetahui letaknya. Sewaktu dilakukan pembacaan ulang, penulis merasa berbahagia karena diperbolehkan melihat tempat penyimpanan tersebut, kemudian dengan arak-arakan yang meriah dan khidmad prasasti itu dibawa ke Langgahan dan selanjutnya dibaca di dalam pura. Mengingat tempat rahasia itu telah diketahui minimal oleh dua orang, waktu itu penulis menganjurkan supaya penyimpanan prasasti yang sangat berharga tersebut dipindah ke desa Langgahan. Hal ini mengingat beberapa prasasti di Bali yang disimpan jauh dari desa ternyata kemudian hilang (diambil oleh warga desa sendiri dan dijual kepada orang asing).

10 Dalam prasasti Turunan tersebut dikatakan, bahwa penduduk desa Air Rawang pada setiap bulan Bhadrawada bertugas menggosok arca Bhatāara Da-Tonta dengan boreh kuning, mengambil air danau dan memandikannya (angkên bhadrawada masa atêhêr to banua di air rawang, manguningin dida bhațāra da tonta di rājakāryyanda, mangalap air danu dirusên da bhațāra, kamamuningin ida). Rājakāryya berarti: upacara besar (raja). manguningin dari kuning, dirus: mandi

1 Perlu diketahui bahwa bentuk huruf (akşara) ka dan ta Jawa Kuna memang agak mirip. Lebih-lebih apabila tulisan tidak jelas (prasasti aus) mudah sekali menim. bulkan (mengakibatkan) kekeliruan. Karena itu perkataan wingkang (pinggir) mudah sekali dibaca salah menjadi wingtang, wintang (bintang). Nama tempat Kwak bisa saja orang keliru membacanya Twak.

12 Lihat catatan No. 2.

13 Lihat Old Javanese - English Dictionary, KITLV. 1982, hlm. 918. Timbul pertanyaan. adakah istilah kulit nini (maternal lineage) dalam bahasa Jawa Kuna?

14 Waktu itu hanya beberapa orang saja yang diperbolehkan masuk ke dalam gêdong untuk melihat Bêtara dan Bêtari Tulukbiyu, yaitu pendeta, pêmangku, beberapa orang tua dan penulis sendiri. Tetapi karena dikeramatkan prêtima mas tersebut tidak boleh dipegang, diukur tingginya, digambar maupun dipotret.

15 Istilah karāman berasal dari perkataan rāma (ayah, ketua, lurah, pamong, pimpinan) mendapat awalan ka-dan akhiran -an. Secara umum berarti desa dengan penduduknya. Istilah karāman terdapat di dalam prasasti Jawa Timur dan Bali.

16 Supaya lebih jelas lihat karangan M.M. Sukarto: "Prasasti Buyan-Sanding-Tamblingan Dari Jaman Raja Jayapangus", makalah dalam Seminar Sejarah Nasional II di Yogyakarta (1970). Keterangan itu penulis ulang lagi dalam buku Sejarah Nasional Indonesia II (Departemen Pendidikan dan Kebudayaan, PN. Balai Pustaka, 1984) Bab VI. BALIDWIPAMANDALA, hlm. 281-395.

17 Pejabat tinggi yang bertugas mengawasi dan menjaga sesuatu. Sebutan (gelar) sang menunjukkan bagaimana pentingnya tugas tersebut. Sang admak (yang memegang, mengawasi), akmitan (yang menjaga) dan apigajih (belum jelas), merupakan gabungan tiga kewajiban yang penting dalam pemerintahan kuna di Bali. Apakah apigajih berkaitan dengan gajih (lemak gajih. bayaran)' $\mathrm{Cf}$ sang mangiläla druyyahaji, yaitu petugas pemungut pajak (yang menikmatı milik raja) 
18. Nāmadewabhişeka berarti: nama penobatan raja, kebalikannya janmotpattināma. yaitu: nama kelahiran, nama kecil

19. Dalam bahasa Bali Baru gêdang berarti: kates (papaya).

20. Kabayan-atuha: kebayan tua, Kabayan ñoman: kebayan muda (nom). Kabayan mungkin dari baya (tua, umur) mendapat awalan ka- dan akhiran -an. Tetapi mungkin pula dari baya (bahaya). Perkataan ñoman menjadi Nyoman di Bali, dan atuha (wayah-an) menjadi Wayan. Kabayan termasuk kelompok tuha-tuhaning karāman (para ketua desa).

21. Argga mungkin pejabat yang berhubungan dengan jamuan atau air suci (air pembasuh kaki tamu terhormat).

22. Cf. Jawa Baru: bèbahu (bahu), pembantu (staf) lurah.

23. Panghet artinya kurang jelas. Apakah berkaitan dengan het, höt, yang berarti: sembunyi, senjata tajam, potong, putus?

24. Dalam kitab Nitisastra, wanita dianggap sumber kekacauan dunia (laki-laki berperang karena berebutan wanita, misalnya antara Rāma dan Rahwana). Juga dikatakan bahwa di dunia hanya tiga hal yang bengkok (tidak lurus), yaitu: lwah (sungai), akar (odwad) dan stri (wanita). Lihat lebih lanjut ceramah M.M.Sukartodi Lembaga Javanologi Yayasan Panunggalan Yogyakarta (tanggal 7 Nopember 1986) dengan judul: Konsep Perkawinan Dalam Masyarakat Jawa Kuno (hlm. 1-37). Tetapi harus diakui pula bahwa kedudukan wanita dalam masyarakat Indonesia Kuna juga cukup tinggi, terbukti banyak raja putri yang bertahta pada jaman dahulu.

25. Lihat M.M. Sukarto: "The Phallic Symbol On The Stone Inscription Of Samirana" (Catatan No. 7).

26. Sewaktu penulis bertugas di Bali berulang-kali menerima berita hilangnya bendabenda purba (budaya) yang tersimpan di dalam pura. Bahkan serombongan penduduk dari Bali Utara melaporkan hilangnya prasasti tembaga (prasasti Indrapura) yang mereka keramatkan. Rupa-rupanya prasasti itu jatuh ke tangan orang asing (orang bule istilah tertentu di Bali) dan tentunya sekarang sudah dibawa pulang ke negaranya (negara tetangga Indonesia). Sewaktu penulis ada di Jakarta, pernah diajak oleh Bapak-bapak dan Ibu ahli purbakala meninjau koleksi benda-benda budaya (purbakala) di sebuah Kedutaan Besar Asing. Mes kipun benda-benda yang diperlihatkan ada yang palsu, tetapi dalam batin men duga, pasti masih terdapat benda-benda budaya (purbakala) lainnya yang tidak ditontonkan. Pendek kata penulis menghimbau kepada yang berwewenang supaya lebih ketat mengawasi masalah penggalian liar, jual-beli benda purba. dan juga mengalirnya benda-benda purba ke luar negeri. Tentu saja pengawasan tidak hanya terhadap orang luar (asing), tetapi juga terhadap orang dalam sendiri. 


\section{REFERENSI}

Atmodjo, S. K. 1970 Prasasti Buyan-Sanding-Tamblingan Dari Jaman Raja Jayapangus, makalah pada Seminar Sejarah Nasional II di Yogyakarta.

Atmodjo, S. K. 1981 Betulkah Astasura-ratna-bumi-banten Seorang Raja Bali Yang Murka Dan Hina (?), makalan pada Seminar Sejarah Nasional III di Jakarta.

Atmodjo, S. K. (1983). MENGAPA PHALLUS ARCA SIWA-BHAIRAWA DI PURA KEBO EDAN MENGHADAP KE ARAH KIRI?. Berkala Arkeologi, 4(1), 48-54. https://doi.org/10.30883/jba.v4i1.303

Atmodjo, S. K. 1986 Konsep Perkawinan Dalam Masyarakat Jawa Kuno, makalah pada Lembaga Javanologi, Yayasan Panunggalan Yogyakarta (tgl. 7 Nopember 1986, him. 1-37).

Atmodjo, S. K. 1986 The Phallic Symbol On The Stone Inscription Of Samirana, dalam buku Untuk Bapak Guru, persembahan para murid untuk memperingati usia genap 80 tahun Prof. Dr. A.J. Bernet Kempers, Pusat Penelitian Purbakala, Departemen Pendidikan, Jakarta, 1986, hlm. 173 - 188.

Goris, Roelof 1954 Prasasti Bali I (Inscripties Voor Anak Wungcu), Lembaga Bahasa dan Budaya (Fakultet Sastra dan Budaya), Universitet Indonesia, N.V. Masa Baru, Bandung.

Goris, Roelof 1954 Prasasti Indonesia II (Inscripties Voor Anak Wungcu), Lembaga Bahasa dan Budaya (Fakultet Sastra dan Budaya), Universitet Indonesia, N.V. Masa Baru, Bandung.

Gosta Liebert 1976 Iconographic Dictionary Of The Indian Religion, E.J. Brill 1976, Leiden.

Poerwadarminta, WJS 1976 Kamus Umum Bahasa Indonesia, Balai Pustaka, 1976, Jakarta.

Zoetmulder S.J, P.J. 1982 Old Javanese - English Dictionary, KI1LV (Koniklijk Instituut vor Taal-, Land- en Volkenkunde, 1982. 